\title{
Effects of Light Intensity and Photoperiod on growth and reproductive performance of Coturnix japonica: A review
}

\begin{abstract}
Asad Ali Khaskheli ${ }^{1, a, *}$
${ }^{1}$ Department of Animal Nutrition, Sindh Agriculture University, Tando jam, Pakistan *Corresponding author

A R T I C L I N F O A B S T R A C T

Review Article

Received : 05/05/2020

Accepted : 23/06/2020

Keywords:

Game birds

Light intensity

Performance

Photoperiod

Production

Present review was performed in order to understand the influence of photoperiod and light intensity on Coturnix japonica. Different literatures were reviewed regarding egg production, behaviour, body weight, feed intake, feed conversion ratio, carcass weight, egg quality with respect to photoperiods and intensities. It was noticed from the reviewed studies that light intensity of 80 and 20 luxes for 8 hours during growing period and 240 and 60 luxes for 16 hours during laying period results $194.85 \pm 4.46,191.42 \pm 2.87$ feed intake, $201.00 \pm 13.82,210 \pm 15.1$ weekly weight gain. The better feed conversion ratio remains (1.03) with light intensity of 80 and 20 luxes for 8 hours during growing period. Carcass weight remains as $98.33 \pm 8.33$ and $99.56 \pm 5.44$, dressing percentage $50.46 \%$ and $52.01 \%$, egg production percent 50.11 and 48.81 , egg length $32.15 \pm 0.54$ and $32.12 \pm 0.35$, egg width $24.87 \pm 0.22$ and $23.75 \pm 0.31$, egg weight $9 \pm 0.44$ and $9 \pm 0.54,11.2 \pm 0.73$ when light intensity of 80 and 20 luxes for 8 hours during growing period and 240 and 60 luxes for 16 hours during laying period is provided. In conclusion Coturnix japonica raised on 80 luxes for 08 hours light intensity during growing period and 240 luxes for 16 hours light intensity in laying period results better FCR and feed intake in cage system. While Coturnix japonica reared with 5 luxes for 16 hours photoperiod during growing period and 15 luxes for 20 hours photoperiod in laying period demonstrate better egg production and behaviour.
\end{abstract}

khaskhelias@gmail.com

(c) (1) () This work is licensed under Creative Commons Attribution 4.0 International License

\section{Introduction}

Coturnix japonica are small sized game birds. They are globally reared on commercial scale for egg and meat production. They have ability of achieving sexual maturity at the age of 5 to 6 weeks. Two species of Coturnix japonica have been most popular for breeding including Japanese quail and the American quails. Coturnix japonica is classified under family Phasianidae. These small birds can migrate between Europe and Asia, thus also called migratory birds (Faitarone et al., 2005). The Coturnix japonica possess several favorable traits including rapid sexual maturity, higher growth rate, higher egg production (300 eggs per Year), small space requirement, smaller generation interval, lower feeding needs, less feed cost, short incubation period, lesser susceptibility to diseases (Jatoi et al.,2013). Being a smallest member of poultry and possession of above said characteristics, Coturnix japonica are nowadays widely used for eggs and meat production on commercial scale. In addition to that farming of these fascinating birds need low capital investment compared to other poultry species (Minvielle, 2004). Coturnix japonica has got much economic importance during last decade due to higher production rate of eggs and meat. These game birds are liked for their unique flavor and taste. In fact current survey shows that quail are found about in all continents. Numerous lines, breeds and varieties have been discovered for different production purposes (Maiorano et al., 2012).

The transition of backyard to commercial poultry production has resulted rearing of Coturnix japonica in large barns or brooder houses which require intensive management and to facilitate the production, Coturnix japonica producers are manipulating and modulating environmental parameters such as temperature, humidity, ventilation, gases, light intensity, light duration and light color (Ojedapo et al., 2014). From these all factors, light is assumed to be the most critical factor for Coturnix japonica farming. Light not only controls many physiological and behavioral processes of bird but it has vital impact on production efficiency, behavior, egg production, and health of Coturnix japonica (Olanrewaju et al., 2006). Thus, practice of artificial lighting is most common for increasing reproductive activity of laying females. The physiological action of light happens when it contact with eyes and converted into nerve impulses that are sent to the brain. The brain then coordinates the stimulus for influencing the pituitary gland to secrete the necessary hormones for 
ovulation (Lewis and Morris, 2000). The impact of light on Coturnix japonica physiology, behavior, performance and reproductive activity is largely due to three factors such as intensity, photoperiod and wavelength. The knowledge in this regards is well documented in the literatures (Kuhles and Petersen, 2005). Thus, current review was planned to investigate the significance of photoperiod and light intensity for Coturnix japonica and to explore possible effects of different types of light regimes on Coturnix japonica.

\section{Coturnix japonica}

Coturnix japonica is concerned to the family Phasianidae and order Galliformes. It is the largest group of birds with diverse characteristics compared to other poultry birds. Phasianidae family is much difficult to divide into natural groups because of several diverse features. However, 3 subfamilies have been classified including Perdicinae, Odontophorinae and Phasianinae (Shanaway, 1994). Among different breeds, Coturnix japonica has major research concern due to unique features such as smaller generation interval, easy maintenance, fast growth rate and higher production of eggs (Tarhyela et al., 2012). These unique characteristics have resulted Coturnix japonica, the bird of choice for commercialization and scientific research worldwide. Studies concerned to egg production and growth performance of Coturnix japonica have been well documented (Vali et al., 2005; Minvielle and Oguz, 2002). Female birds become matures at the age of 6 weeks and start laying eggs within approximately 7 weeks of age. These small birds can produce 4 generations in a year and that makes them most suitable and effective poultry bird on commercial scale (Onyewuchi et al., 2013). Female birds attain live body weight ranging from 120 to $160 \mathrm{~g}$ at maturity, however males range from 110 to $140 \mathrm{~g}$ (Figure 1). The egg weight (average) remains $10 \mathrm{~g}$, while newly hatched has been reported $7 \mathrm{~g}$ (Figure 2). They lay their eggs mostly at evening time. Eggs' incubation period ranges from 17 to 18 days (Saidu et al., 2014). The eggs of Coturnix japonica are popular due to their unique color and mottles and preferred by consumers throughout Easter (Figure 3). They may be valuable supplements due to high quality products for human. The eggs have lower fat content compared to chicken eggs, while the cholesterol levels remain similar. Eggs are richer in essential amino acids and minerals than the chicken eggs (Tolik et al., 2014).

\section{Effect of photoperiod and light intensity on feed intake, weight gain and feed conversion ratio of Coturnix japonica}

The variety of light regimes are applied for attaining maximum performance from Coturnix japonica. Favorable results were recorded with light duration of 24 hours or 23hours and 1hour dark period (Pieter et al., 2013). In a study, researchers examined the influence of five different lighting regimes and stated that carcass weight declines with decrease of photoperiod. The effect is more influential in female Coturnix japonica compared to males (Watkin et al., 2014). Higher body weight gain rates in birds may be to less energy expenditure and better feed intake by the birds. The interaction among energy intake and expenditure significantly affects the overall performance of birds particularly body weight gain (Farzinpour et al., 2013). Overall body weight gain increases by modulating the light duration and consequently decreasing dark period for birds to improve intake It is evident that consequences of food activity depends upon the photoperiod. More light duration simultaneously results more intake of feed, less feeding duration and balance digestion which ultimately results maximum weight gain of birds (Hassan, 2013). Light regimes restriction in Coturnix japonica improves performance by decreasing physical activity and save energy expenditure. A light period of 08 hours in Coturnix japonica furnishes the best body weight Table 1 (Imelda et al., 2016).

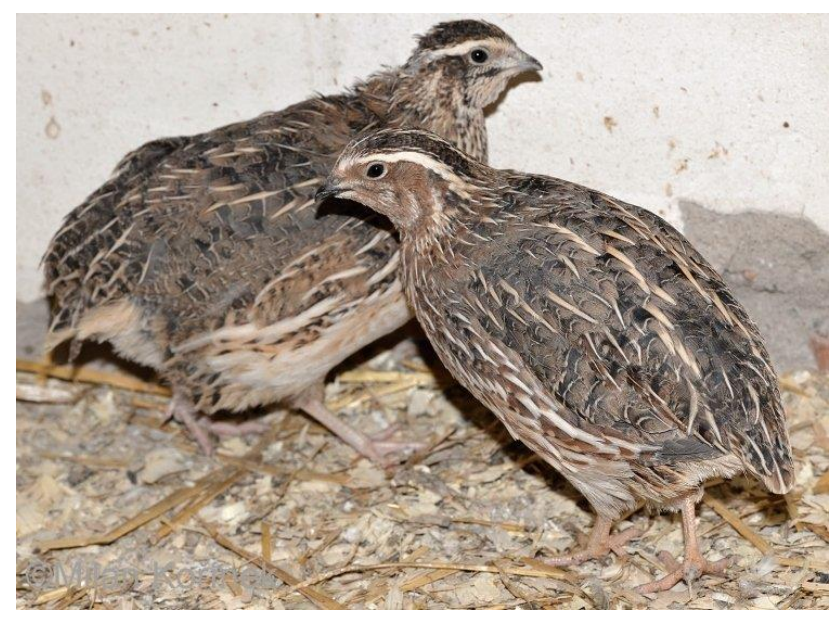

Figure 1. Male (right sided) and female (left sided) Coturnix japonica

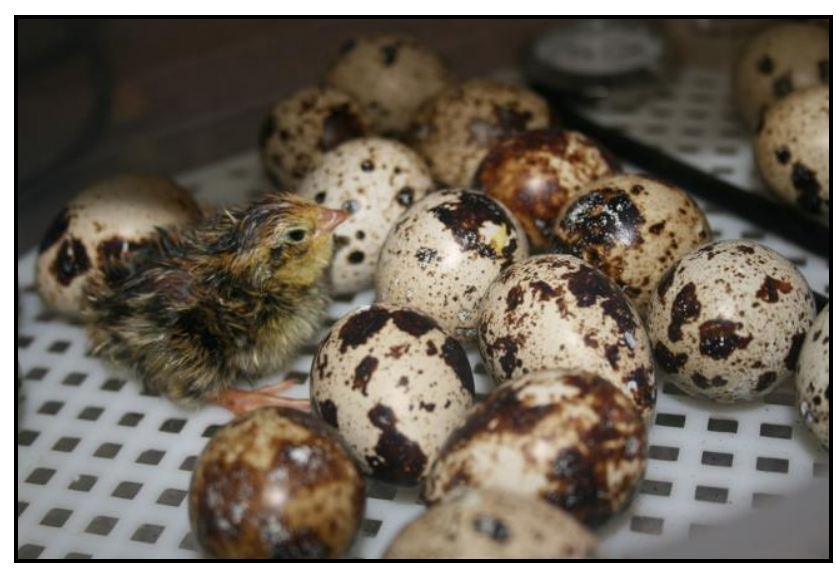

Figure 2. Newly hatched chick of Coturnix japonica

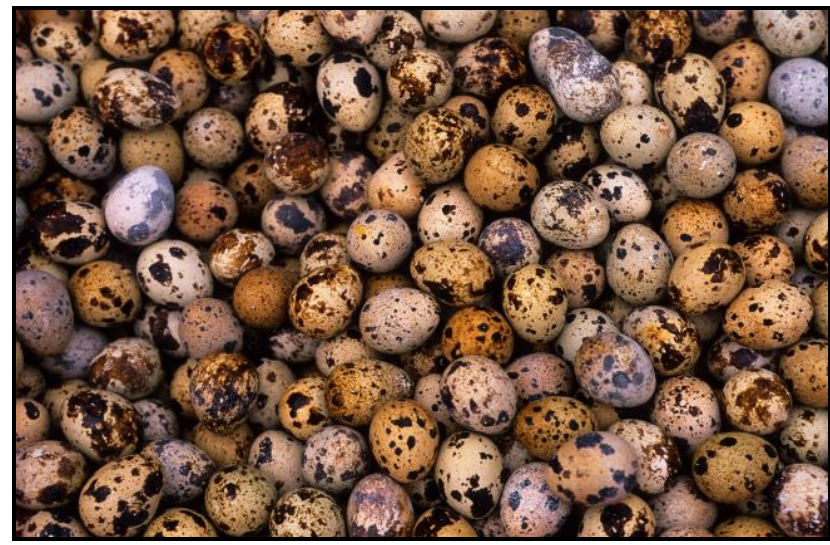

Figure 3. Eggs of Coturnix japonica having spots on shell as characteristic feature 
Table 1. Performance of Coturnix japonica at different light durations

\begin{tabular}{l|ll}
\hline SN & \multicolumn{1}{|c}{ Light duration } & Influence on performance \\
\hline 1 & 8 hours/day & Higher body weight \\
\hline 2 & 12 hours/day & $\begin{array}{l}\text { Consume lower quantity of } \\
\text { feed }\end{array}$ \\
\hline 3 & 20 hours/day & Highest feed intake \\
\hline 4 & 15 hours/day & Increased eggs production \\
\hline 5 & $\begin{array}{l}\text { Lower than 15 } \\
\text { hours/day }\end{array}$ & $\begin{array}{l}\text { Less eggs production/ } \\
\text { cessation of laying }\end{array}$ \\
\hline
\end{tabular}

Feed intake of Coturnix japonica is significantly affected by light type and its duration provided to birds (Table 1). Birds with 12hours light duration consume lower quantity of feed. However highest feed intake is seen when longer light duration (20hours) is provided. It may be argued that artificial lighting might increase the stress condition and in response to that birds consume large quantity of feed (Jatoi et al., 2013). It has also been reported that the light sufficiently affect poultry house round the clock. (Khalil et al., 2014). The reproductive performance of birds is considerably influenced by light duration and intensity. Change in growth of Coturnix japonica was recorded in contrast to light intensity and duration (Lucian et al., 2012). Light duration has been proved to be major welfare aspects for the rearing of poultry birds. Light with duration more than 15 hours/day increase eggs production, while less duration (lower than 15hours) cause less eggs production and cessation of laying as shown in the Table 1 (Fairchild, 2007). Duration of light supply in the poultry house significantly improved the reproductive performance and production of the Coturnix japonica (Mase and Oishi, 2013). Further feed conversion efficiency as the index of body mass considerably influenced by illumination. Improvement in feed conversion efficiency is noticed when light duration remains shorter as well as longer (Nunes et al., 2014; Omer et al., 2015).

\section{Effect of photoperiod and light intensity reproductive parameters of Coturnix japonica}

Among environmental factors light is of utmost importance Coturnix japonica. This factors influences the reproductive activities, behavior, performance, production and overall health of laying females. Thus, artificial lighting with different light duration and intensity is widely used for increasing performance of laying females in the houses (Rozenboim et al., 1998). Light has been reported as main influencing factor for several physiological processes in the birds. Egg production and quality is highly affected by light source, light intensity, light duration and light color. The influence of light intensity (LI) on laying hens has been critically studied with special focus on age at first egg and egg production rate. Light intensity lower than 4 luxes delays the sexual maturity of females raised under cage system (Nicholls et al., 1988). In another study, dose related increase in egg production of hens in three tiered cages (LI of 0.2, 1 and 5 luxes 44) was measured. Birds were managed on 0.2 luxes laid eggs at 9 to 12 days later compared to birds raised on 1 and 5 luxes. Diverse light spectrums have been reported to influence the birds' growth, behavior and production (Sultana et al., 2013), thus understanding the influence of several types of light on poultry birds utmost important for growing industry. Light emitting diodes (LEDs) is considered as most superior to other lights sources in terms of durability, energy savings, and longevity (Benson et al., 2013). Multiple factors essentially be taken into account when evaluating cage lighting system like light period, light spectrum, and light intensity. Among all aspect of bird lighting, light period is most probably studied because it is assumed to be very important for proper management of Coturnix japonica and can increase growth efficiency in Coturnix japonica. Light spectrum is actually the combination various electromagnetic radiation with different wavelengths which are emitted from light source. The visual range of poultry and other animals is different. The most striking fact is the inclusion of ultraviolet light, which have diverse range due to addition of $4^{\text {th }}$ type of photoreceptor (Osorio et al., 1999). Supplemental addition of UV light has been reported to increase sexual activities, mating behavior, egg output and behavior compared to control birds with normal lighting fluorescent of Forty Five lights (Jones et al., 2001). The use of artificial lighting for inducing laying potency of females has been considered as the most important contribution for the improving egg production of Coturnix japonica (Shanaway, 1994). Light duration of 14 to 18 hours/day is assumed to be very important for Coturnix japonica for maintaining peak production of eggs and fertility. Supplementary light is essential in the winter, autumn and spring months for maintaining the reproductive activities and production Coturnix japonica (Randall and Bolla, 2008). Freitas et al. (2005) studied the influence of intermittent lighting, natural lighting, one day increasing lighting and continuous lighting on performance of Coturnix japonica during end of laying cycle. Researches show that 5.38 lux light intensity is assumed to be optimum for maximum egg production in dark houses for layers (Skouglund et al., 1975). Recent researches show that 10 lux is needed at cage or bird's head height in opensided houses. Wild Coturnix japonica have been reported to lay 7 to $14 \mathrm{eggs} /$ Year. On other hand domestic Coturnix japonica can lay approximately 280 eggs in a Year (Puigcerver et al., 2007).

In Coturnix japonica of subtropical and temperate latitudes, photoperiod (gradual/abrupt) increase initiates the gonad recrudescence and laying activity. Reduction in day length (short photoperiod) delayed the onset of sexual maturity and even terminated egg laying in the birds (Yadav and Chaturvedi, 2015). The wavelength of light influenced the egg components, shell quality and overall egg production of the laying hens. Application of longer photoperiod favored egg production in cage system. A reduction in light duration resulted reduced eggs production and laying sequence length (Zawilska et al., 2015). Light type, intensity and duration significantly influenced the birds' health. No improvement was recorded with the use of high intensity, light during and short day light restriction on subsequence reproductive efficiency. Percentage of eggs/hen/day was prominently decreased by photoperiods of 23 to 26 weeks and 31 to 34 weeks. This reduction photoperiod caused considerably impact on hen day egg production percent. In addition to 
sexual maturity, light has also been reported to affect egg production in many avian species (Watkins, 2014).

\section{Conclusions and Recommendations}

In conclusion Coturnix japonica reared under cage system with 80 luxes for 8 hours light intensity during growing period and 240 luxes for 16 hours light intensity in laying period show better FCR and feed intake, while Coturnix japonica reared with 5 luxes for 16 hours photoperiod during growing period and 15 luxes for 20 hours photoperiod in laying period demonstrate better egg production. In view of the present review findings, it is recommended that Coturnix japonica must be housed under photoperiod of 5 luxes for 16 hours duration during laying period for getting maximum egg production as well as hen day egg production. Further studies concerned to influence of photoperiod and light intensity should be conducted on biochemical and production parameters of other poultry birds for better understanding and improving the breed production.

\section{References}

Benson ER, Hougentogler DP, McGurk J, Herrman E Alphin RL. 2013. Durability of incandescent, compact fluorescent and light emitting diode lamps in poultry conditions. Applied Engineering Agriculture, 29: 103-111.

Fairchild B. 2007. Study of different lighting sources on the egg production. Journal of veterinary sciences, $6: 30-35$.

Faitarone ABG, Pavan AC, Oliveira S, Garcia RP. 2005 Economic traits and performance of italian quails reared at different cage stocking densities. Brazil Journal Poultry Science, 7: 19-22.

Farzinpour A, Karashi N, Nanosci A. 2013. The effects of nanosilver on egg quality traits in laying Japanese quail. Journal of Poultry Science, 3: 95-99.

Freitas HJ, Cotta JTB, Oliveira AI, Gewehr CE. 2005. Avaliacao de programas de iluminacaosobreo desempenho de poedeirasleves. Ciencia e Agrotecnologia, 29: 424-428.

Hassan AK, Hanafy AM, Akrum M, Hamdy MM. 2016. Effect of artificial and natural day light intensities on some behavioral activities, plumage conditions, productive and physiological changes for Japanese quail. Asian Journal Poultry Science, 10: $52-63$.

Imelda S, Beat W, Wechsler E. 2016. Identification of key nest site stimuli for Japanese quail (Coturnix japonica). Journal of Animal Science, 55: 151-159.

Jatoi AS, Sahota AW, Akram MK, Javed J, Hussain M. 2013. Response of different body weights on blood serum chemistry values in four close-bred flocks of adult Japanese quails (coturnixcoturnix japonica). Pakistan of Journal Zoology, 45:1215-1220.

Jones EKM, Prescott NB, Cook P, White RP, Wathes CM. 2001. Ultraviolet light and mating behavior in domestic broiler breeders. British Poultry Science, 42: 23-32

Khalil HA, Hanafy AM, Hamdy AMM. 2014. Effect of artificial and natural day light intensities on some behavioral activities, plumage conditions, productive and physiological changes for Japanese quail. Journal of Poultry Science, 12: 124-132.

Kuhles A, Petersen J. 2005. Einfluss von licht und dunkelheit auf den adaptations prozess be imhuhnerkuken - literature bersicht. Archgeflugelk, 69: 2-10.

Lewis PD, Morris TR. 2000. Poultry and colored light. World's Poultry Science Journal, 56: 189-207.
Lucian I, Micloşanu E, Cornel P, Custură I, Şerbănoiu C. 2012. A review on some parameters of environment in youth intensive raising of Japanese quail. Journal of Animal Science and Biotechnology 45: 419-425

Maiorano G, Sobolewska A, Cianciullo D, Walasik K, Elminowska-Wenda G, Sławinska A, Tavaniello S, Zylinska J, Bardowski J, Bednarczyk M. 2012. Influence of in ovo prebiotic and synbiotics administration on meat quality of broiler chickens. Poultry Science, 91: 2963-2969.

Mase Y, Oishi T. 2013. Effects of photoperiods on the weights of bursa of Fabricius and thymus in Japanese quail. Journal of Poultry Science, 56: 984-990.

Minvielle F. 2004. The future of Japanese quail for research and production. World's Poultry Science Journal, 2: 500-507.

Minvielle F, Oguz Y. 2002. Effect of genetic and breeding on egg quality of Japanese quail. World Poultry Science Journal, 58: 291-295.

Nicholls TJ, Goldsmith AR, Dawson A. 1988. Photorefractoriness in birds and comparison with mammals. Physiology Review, 68: 133-176.

Nunes KCI, Garcia RG, Nääs IA, Eyng CI, Caldara FR, Sgavioli SI, Roriz BCI, Ayala CMI. 2014. Effect of led lighting colors for laying Japanese quails. Brazil Journal Poultry. Science, 20: $547-542$

Ojedapo LO, Amao SR. 2014. Sexual dimorphism on carcass characteristics of japanese quail (coturnixcoturnix japonica) reared in derived savanna zone of nigeria. International Journal Science and Environment Technology, 3: 250-257.

Olanrewaju HA, Thaxton JP, Dozier WAI, Purswell J, Roush WB, Branton SL. 2006. A review of lighting programs for broiler production. International Journal Poultry Science, 5: 301-308.

Omer C, Lacin E, Sabuncuoglu N, Ozudogru Z. 2015. Effect of self-photoperiod on live weight, carcass and growth traits in quails (Coturnix Coturnix Japonica). Asian-Australasian Journal of Animal Science, 22: 410-415.

Onyewuchi UU, Offor IR, Okoli CF. 2013. Profitability of quail bird and egg production in imo state. Nigerian Journal of Agriculture, Food and Environment, 9: 40-44.

Osorio D, Vorobyev M, Jones CD. 1999. Color vision of domestic chicks. Journal of Experimental Biology, 202: 2951-2959.

Pieter R, Herodes J, Jager D. 2013. Effect of photoperiod on sexual development, growth and production of quail (Coturnix coturnix japonica). Journal of Poultry Science, 89: 741-746.

Puigcerver M, Vinyoles D, Rodrìguez-Teijeiro JD. 2007. Does restocking with Japanese quail or hybrids affect native populations of common quail Coturnix coturnix?. Biological Conservation, 136: 628-635.

Randall M, Bolla G. 2008. Raising Japanese quail. Primefacts, 602: $1-5$.

Rozenboim I, Zilberman E, Gvaryahu G. 1998. New monochromatic light source for laying hens. Poultry Science, 77: 1695-1698.

Saidu S, Afanasyev G, Komarchev A, Ibrahim U. 2014. Dynamic of reproductive qualities of Japanese quails. International conference on earth, environment and life sciences, (eels2014) December 23-24, Dubai.

Shanaway MM. 1994. Quail production systems: a review, Food Agriculture Organ. The. Unit. Nations. Rome. pp. 73-79.

Skouglund WC, Palmer DH, Wabeck CJ, Verdaris JN. 1975. Light intensity required for maximum egg production in hens. Poultry. Science, 54: 1375-1378.

Sultana S, Hassan MR, Choe HS, Ryu KS. 2013. The effect of monochromatic and mixed LED light color on the behavior and fear responses of broiler chicken. Avian Biology Research, 6: 207-214. 
Tarhyela R, Henab S, Tanimomo B. 2012. Effects of age on organ weight and carcass characteristics of Japanese quail (Coturnix Japonica). Science Journal Agriculture, 1: 21-26.

Tolik D, Ewa P, Anna C, Sebastian N, Ross C. 2014 Characteristics of egg parts, chemical composition and nutritive value of Japanese quail eggs - a review. Folia Biologica (Kraków), 62: 287-292.

Vali N, Edriss MA, Rahmani HR. 2005. Genetic parameters of body and some carcass traits in two quail strains. International Journal of Poultry Science, 4: 296-300.
Watkins S. 2014. Poultry Lighting: LED Bulbs Provide Energy Savings and Durability in Division of Agriculture Research \& Extension. U. o. Arkansas ed., University of Arkansas Cooperative Extension Service Printing Services.

Yadav S, Chaturvedi CM. 2015. Light colour and intensity alters reproductive/seasonal responses in Japanese quail. Journal of Physiological Behavior, 11: 163-168.

Zawilska JB, Lorenc A, Berezińska M, Roels BV, Pevet P, Skene DJ. 2015. Photoperiod-dependent changes in melatonin synthesis in the Japanese quail pineal gland and retina. Journal of Poultry Science, 86: 1397-1405. 